\title{
Heading Towards Online Dispute Resolution in the Slovak Republic
}

\author{
TOMÁŠ GÁBRIŠ*
}

\begin{abstract}
The paper highlights the various aspects of the electronisation of judicial and extra-judicial dispute resolution in the Slovak Republic. The author concludes that arbitration as a form of dispute settlement process may take an electronic form in Slovakia, with the exception of issuing the arbitration decisions which must always take a paper form - for the sake of legal certainty. An alternative dispute resolution in consumer disputes, taking the form of mediation is a novelty in Slovakia and was only introduced in 2016, under the respective EU Regulation. This also foresaw an electronic platform to facilitate online cross-border consumer dispute resolution. Finally, the recently introduced new rules on civil judicial procedure in Slovakia (1st July 2016) also brought about some enhancements with regard to electronisation of dispute resolution. In addition to the possibilities of filing electronic submissions, hearings can also take place with the use of electronic means; public notices must be published on a website of a court or relevant authority and the delivery of court documents was also widely electronised based on a recent Act on e-Government.
\end{abstract}

Keywords: online dispute resolution, arbitration, mediation, Slovak Republic

\section{INTRODUCTION}

This article focuses on the challenges and opportunities that court trials face in the period of electronisation, leading to introduction of various forms of online dispute resolution. ${ }^{1}$ Thereby, the specific situation in the Slovak Republic will only be studied but this will not be solely limited to judicial proceedings. Extra-judicial settlement of disputes via arbitration and via newly established alternative dispute resolution procedures for consumer disputes will also be introduced. This paper was given the broad title of 'Online Dispute Resolution', under which label has the issue of electronisation of dispute settlement been dealt with by the UNCITRAL for a long time. ${ }^{2}$ Emphasis will be thereby placed on the arbitration and the possibilities of an online arbitral proceedings, representing a possible future trend in the online dispute resolution.

A practical benefit of this paper should foremost be the evaluation of current possibilities of using electronic means in the course of judicial and extra-judicial dispute resolution process, but also of their use in non-contentious proceedings and proceedings of judicial review in administrative matters (administrative judiciary). Hence, the centre of attention will not be exclusively 'disputes'. However, as a caveat, no attention will be paid to the enforcement (execution) proceedings.

Throughout the article, latest Slovak legal regulation will be used as an example of electronisation of dispute resolution, hopefully providing the other Central and Eastern

* Attorney-at-Law and Professor at the Comenius University in Bratislava, Faculty of Law, being the Head of Department of Theory of Law and Social Sciences. He is teaching courses on Cyber Law, Law and Technology, and Legal Theory. He was a member of the Commission of Ministry of Justice of Slovak Republic for recasting civil procedure and currently is a member of the Commission for recasting private law in Slovakia. E-mail: tomas.gabris@flaw.uniba.sk.

${ }^{1}$ Comprehensively on the individual forms of online dispute resolution see Hörnle (2009).

2 Brand (2012-2013) 11 et seq. See also Hörnle (2012) link 1. 
European countries, in the process of recasting their law-codes and procedural rules, some possible routes and solutions to modernization of their own regulation of dispute resolution.

In structure, the contribution begins with the possibilities of e-arbitration in Slovakia under the current regulation of arbitration as effective from $1^{\text {st }}$ January 2015 (divided into two forms; commercial and consumer arbitration), then goes through the online resolution of consumer disputes outside the arbitration (under rules effective as of 1 February 2016, but still not widely used), to finally ends up with the electronisation of judiciary in the newly adopted procedural codes - Code of Civil Contentious Litigation, Code of Civil Non-Contentious Litigation, and Code of Administrative Judicial Procedure, all three being effective as of 1 July 2016. It is especially the electronisation of judicial proceedings in these three codes that can possibly serve as a model for other countries seeking for modernization of their procedural rules.

\section{EXTRA-JUDICIAL DISPUTE RESOLUTION ONLINE}

Extra-judicial dispute settlement, also called 'alternative dispute resolution' (ADR) has witnessed a strong trend in electronisation recently, ${ }^{3}$ even leading to adoption of an ODR ${ }^{4}$ label standing for the 'online dispute resolution'. ${ }^{5}$ This is to designate a form of dispute resolution, where the bulk of the dispute resolution process takes place online, in electronic form. ${ }^{6}$ The electronisation trend in dispute resolution is thereby clearly seen both at the level of non-binding documents, as well as in the legally binding norms of the European Union e.g. Recommendation 2001/310/EC on mediation, where Article 9 contains a reference to the use of electronic means in mediation; in 2013, even a special EU Regulation no. 524/2013 was adopted, expressly providing for ODR in relation to the settlement of consumer disputes (to be discussed infra). ${ }^{7}$

The Slovak Republic has taken account of this ADR/ODR development in the Arbitration Act no. 244/2002 Z.z., in the new Act on Consumer Arbitration no. 335/2014 Z.z., and also in the most recent Act on alternative dispute resolution in consumer matters which explicitly acknowledges the ODR option in cross-border consumer disputes. However, at the national level, the Act does not explicitly provide for the ODR, which may be one of the reasons for its actual non-existence in Slovakia in this type of domestic disputes.

3 On this trend, see Lodder and Zeleznikow (2010).

${ }^{4}$ An important source of information on this issue is the website Online Dispute Resolution (2017) link 2.

5 The first important publication on ODR was: Katsh and Rifkin (2001). From among more recent ones see mainly two works: Poblet (2011); and Abdel Wahab, Katsh and Rainey (2012).

${ }^{6}$ Albornoz and González Martín (2012) 48. A distinction is drawn there between 'computer assisted' dispute settlement (and when it comes to mobile phones rather than computers, authors speak instead of 'technically mediated' dispute settlement) and 'computer based' settlement of disputes where in the former case technologies are used only as an aid to facilitate the process of dispute resolution, while in the latter case technologies are used to make decisions without a direct participation of human arbitrator or mediator. On the different types and forms see also: Breaux (2015) 3.

7 On the preparatory process for adoption and on the theoretical basis of ODR in consumer disputes see Cortés (2010). See also Cortés (2011). 
Furthermore, this text offers a detailed analysis on the potential use of electronic means in all three abovementioned ways of extra-judicial dispute resolution applicable in Slovakia: arbitration in the form of Commercial Arbitration (B2B - business to business), arbitration in the form of consumer arbitration ( $\mathrm{C} 2 \mathrm{~B}$ - consumer to business) and finally the alternative resolution of consumer disputes outside arbitration (taking an actual form of mediation ${ }^{8}$ ).

\subsection{Commercial Arbitration online?}

In the Slovak Republic, the most important and most widely used method of extra-judicial dispute resolution is arbitration. The amendment to the Arbitration Act no. 244/2002 Z.z. (hereinafter referred to as 'AA'), effective from 1 January 2015, brought the wording of the AA yet closer to the international models of arbitration, namely to the UNCITRAL Model Law of 1985 and the New York Convention on the Recognition and Enforcement of Foreign Arbitral Awards of 1958. Although the UNCITRAL Model Law is a relatively older text, it has surpassed throughout its existence various changes and currently even takes into account the electronisation of arbitration as a recent trend - albeit only in relation to the possibility of electronic concluding of an arbitration agreement or arbitration clause. For the sake of compatibility with the Model Law, the latest amendment of the Slovakian AA did not substantially deviate from this minimalist electronisation of arbitration and, hence, does not provide for express provisions on electronic (online) arbitration. However, electronic or online forms of arbitration are quite common in some countries ${ }^{9}$ and therefore the issue of online arbitration in the Slovak Republic naturally arises, as well as the enforceability of foreign online arbitration awards. This issue might thereby be of interest for both Slovakian as well as foreign lawyers, be it practitioners or theoreticians. It may also be of special interest for legislators in drafting possible amendments to their current national rules on regulation - in order to take into account the trends of electronisation and explicitly provide for an e-arbitration.

The issue of enforceability of foreign arbitral awards is yet again regulated at the international level only by a somewhat older document - the already mentioned New York Convention of 1958, which does not mention explicitly any aspects of online arbitration. It does not even address the electronic form of arbitration agreement (clause). The Art. II(2) of the New York Convention of 1958 only stipulates that the arbitration clause (agreement) must be in writing and signed by the parties, whilst acknowledging the conclusion of such a clause or contract through an exchange of telegrams. The electronic form of concluding an arbitration agreement, of course, did not exist at the time of drafting the Convention. Nevertheless, the interpretation of the Convention has gradually accepted the electronic form of an arbitration agreement or clause both in theory and in practice. ${ }^{10}$ Finally, in 2006, an interpretation of the New York Convention and of its Art. II was adopted together with changes to UNCITRAL Model Law, expressly advising to recognize any form of arbitration agreement or clause (i.e. including electronic clauses). Unfortunately, the issue of e-arbitration or recognition and enforceability of electronic arbitral awards has not been

8 The general rules on mediation in Slovakia are disregarded as mediation is rather underdeveloped and not widely used.

${ }^{9}$ An exclusively online arbitration was unveiled with effect from 1 January 2015 by the Chinese Chamber of Commerce (2017) link 3. See also the Dutch e-Court (2017) link 4.

10 Schiavetta (2004) link 5. 
addressed in the interpretation of the Convention nor in the Model Law at that point and is still missing in both documents.

In response to the possibilities of electronisation of arbitration, the AA of the Slovak Republic adheres to the 2006 interpretations and recognizes the electronic form of an arbitration agreement or clause explicitly. Namely, according to Sec. 4(3) AA, a written form of an arbitration agreement is maintained even

a) if the arbitration agreement is included in the mutual written communication of parties or

b) if it has been concluded by electronic means, which allow for preservation of the content of the legal action and the identity of person who performed the action.

In addition, under Sec. 4(4) AA, the reference in a contract or in a written communication between the parties to any document containing an arbitration clause is deemed to be a written arbitration agreement itself, should such a reference express the will of both parties to include the arbitration clause into their contract.

Consequently, this wording of the AA means that an arbitration agreement or clause may take the form of electronic communication in Slovakia, and even of such a communication which simply refers to an arbitration agreement or clause included in another document. Thereby it is not required that such a communication is signed with a qualified (advanced) electronic signature under a special Act.

Concluding an arbitration agreement or clause in the electronic form is thus expressly permitted under the Slovakian AA. However, questions are present regarding the possibility of an online arbitration procedure in its whole - starting from the motion, going through the hearing itself, taking evidence, up to the proclamation of the final decision.

In resolving the question of fully electronic/online method of arbitration in Slovakia, the possibility of lodging the motion for arbitration in electronic form itself is not problematic. Electronic motion can basically be accepted as in similar cases. Electronic action (application) is being accepted within official judicial proceedings, especially with respect to subsidiary applicability of the Code of Civil Contentious Litigation as a general procedural norm for dispute resolution proceedings, both judicial and extra-judicial (including arbitrations under AA). ${ }^{11}$ Particularly if such a possibility is being recognized by the Rules of Procedure of the specific arbitration court and the court has published an e-mail address for the purposes of electronic communication and file submission.

A greater legal issue arises with respect to electronisation of arbitration when taking into account those AA provisions which regulate the venue, delivery, hearing and production of the decision. According to Sec. 23(1) AA, arbitration will be held at the venue agreed by the parties to the arbitration. If the parties not agree on the venue, it is to be designated by the arbitral tribunal with regard to the nature of the dispute and interests of the parties to the arbitration. Thereby, arbitration taking place before a permanent court of arbitration usually takes place at the seat of the court of arbitration under the provisions of the Rules of Procedure of the relevant court. Still, under Sec. 23(2) AA, should the parties to the arbitration not agree otherwise, the tribunal may carry out various procedural steps at any place it deems

11 Sec. 51(3) AA: 'If some issues of the proceedings can not be resolved under this Act, general provisions on court proceedings shall apply mutatis mutandis, if the nature of the case allows this.' The general regulation is the Code of Civil Contentious Litigation (as of 1 July 2016 replacing the previous Code of Civil Procedure). 
appropriate, especially with respect to consultations among arbitrators, hearing witnesses, experts or parties to the arbitration, and examination of goods, property, or documents. This does not mean a change in the place of arbitration set under Sec. 23(1) AA.

Hence, this wording does not preclude that Rules of Procedure may provide for the proceedings taking place in cyberspace, i.e. electronically, while officially the venue will be the seat of the court of arbitration. ${ }^{12}$ Sec. 23(2) AA similarly does not preclude that hearing of parties or witnesses or other individuals may take place electronically, using the means of electronic communication.

In relation to delivery of documents, Sec. 25(1) and 25(2) AA read that unless the parties to the arbitration have agreed otherwise, the documents are considered delivered if delivered to the addressees in person or to the place of their seat, residence, or place of business. However, this wording allows for the parties to have agreed otherwise and if the parties not agree otherwise, Sec. 25(3) also acknowledges that 'the consignment shall be considered delivered upon delivery to the mail box under rules of a special regulation', Act on e-Government no. 305/2013 Z.z.

The provisions of Sec. 25(1) and 25(2) AA shall, however, not apply to serving judicial documents, which means that concerning the service of documents by the court of arbitration, parties may not agree on a change to the rules of delivery of court documents. The delivery of court documents is thus to be governed by the general rules of civil contentious litigation (i.e. the Code on Civil Contentious Litigation effective as of 1 July 2016). ${ }^{13}$

Still, some doubts remain here as to whether the rules on the service of judicial documents can be set in a different manner by the Rules of Procedure of the court of arbitration i.e., not by an agreement of the parties to the arbitration, which would introduce other kinds of electronic delivery than recognized by the Code on Civil Contentious Litigation i.e., the one regulated under the Act on e-Government. The AA does not expressly provide nor excludes this option. Under Sec 14(1) point a) of the AA, Rules of Procedure of a court of arbitration govern the proceedings before the permanent court of arbitration, which includes also the issue of service of judicial documents. Thereby, under Sec. 14(2) AA only 'in matters not covered by the rules of procedure or in matters not agreed upon in an arbitration agreement, the court of arbitration acts under the provisions of this Act.' The rule of the thumb should thus be that the permanent court of arbitration may adjust the rules for service of court documents in its Rules of Procedure. This conclusion can be drawn also from conjunction with Sec. 26(3) AA on written or oral proceedings, which states that

permanent court of arbitration prepares and conducts the arbitration proceedings under the rules of procedure (Sec. 14) effective as of the date of start of the proceedings. Except in cases where this Act precludes this, the permanent court of arbitration may modify the rules on proceedings in its rules of procedure, deviating from this Act.

The Rules of Procedure should therefore take precedence before the rules of the AA, only with an important limitation in Sec. 26(3) AA, final sentence 'The court must see to ensure equality of parties to arbitration and the right of each party to arbitration proceedings to act before the arbitration court.'

12 This solution is proposed by Abdel Wahab (2012) 422.

13 In the sense of the abovementioned Sec. 51(3) AA. 
Another more problematic limitation with respect to e-arbitration in Slovakia, is that the arbitral award in accordance with Sec. 34 AA must always take a paper form - an electronic form of award is explicitly excluded in Slovakia. This is in clear contrast with some foreign legal regulations containing provisions under which an award is executed 'in writing', encompassing also an electronic form of 'writing'. ${ }^{14}$ Sec. 34 AA thus represents a major challenge for a purely electronic (online) type of arbitration in the Slovak Republic. This is also highlighted in the Explanatory Memorandum to the AA, explicitly prohibiting Slovakian courts of arbitration to issue an electronic arbitral award, using the argument of legal certainty. ${ }^{15}$

A question of recognition and enforcement of foreign electronic awards in the Slovak Republic quite naturally, arises at this point. Under Sec. 47 AA, the party seeking for recognition and enforcement of a foreign arbitral award is required to file a written application for recognition and enforcement of foreign arbitral award, accompanied by the original of the foreign arbitral award or a certified copy thereof, and the original arbitration agreement or a certified copy of the agreement. The actual application for recognition can thus be filed in a written form, meaning equally either paper or electronic form, and it must include attached original (or a certified copy) of the arbitration agreement (clause) and of the award.

Recognition and enforceability of arbitral awards is regulated at the level of International Law by the above mentioned New York Convention of 1958. The Convention does not, however, address electronic awards explicitly, as already noted. Still, the 2006 interpretations of the New York Convention and its Art. VII together with the changes to the UNCITRAL Model Law envisage yet broader guarantees for the recognition of foreign arbitral awards than before - in principle this means that individual states should be open to recognition of a foreign arbitral award (thus acting favor arbitri), including e-awards, especially if their national law recognizes electronic/online arbitration and electronic awards. In the case of the Slovak Republic, electronic awards are not allowed under the AA and therefore it may be questionable whether a foreign e-award would be recognized by the Slovakian authorities. Such a situation has not occurred yet, to the best of our knowledge and it can be only hypothetically considered whether the paper form of an award as required by the AA is to be considered a part of public order of the Slovak Republic, being in itself a reason for potentially refusing a recognition of a foreign award under Sec. 50(2) AA. The Author's view is that the public order exception should be used only in exceptional circumstances and also considering that Sec. 50(1) AA considers a foreign award not recognizable and not enforceable only where the award was pronounced contrary to the law of the State under which the decision was issued, should the domestic law of the award allow for electronic form, there is probably no serious reason to refuse recognition of such an award in Slovakia. Hence, it is our opinion that the basic rule applied here should be the favor arbitri rule, i.e. the courts in Slovakia should decide in favour of arbitral dispute resolution, and in favour of recognition of an e-award. This could seemingly lead to a certain inequality between domestic and foreign arbitral awards and this would only be due

14 E.g. in the US under The Revised Uniform Arbitration Act of 28 August 2000. See Abdel Wahab (2012) 424, 426.

15 According to the Explanatory Memorandum to the Arbitration Act no. 244/2002 Z.z. (print no. 1126) (2002) link 6: 'The electronic form of the arbitral award shall not be admissible even if it should otherwise meet all the general requirements of a written form of a legal act.' 
to the restrictive domestic rules of the Slovak Republic on the form of the award, while recognizing and respecting foreign legal regulations.

Still, for the reasons of legal certainty and in conjunction with account experience from other countries, it is often recommended by foreign experts to always request a paper version of an arbitral award, where possible. ${ }^{16}$ While this can be relatively easy to do in most cases as it involved printing the award and having it signed by the arbitrators, this can get more complicated in some cases especially if the arbitrators decide online from different parts of the world.

To conclude, this analysis of e-arbitration in Slovakia in the form of commercial arbitration shows that no major barriers to the electronisation of arbitration exist in Slovakia, except for the rule on a paper form of the arbitral award. The solutions presented and the challenges exposed could thereby help not only the Slovakian legislator to make the next step towards embracing a fully electronic/online e-arbitration. This might be of a wider importance than expected as this move could namely make the country using this form of arbitration an interesting harbour even for solving disputes originating from abroad.

\subsection{Consumer Arbitration online?}

A separate type of arbitration in consumer disputes was introduced in Slovakia as of $1^{\text {st }}$ January 2015 by the Act no. 335/2014 Z.z. on Consumer Arbitration (hereinafter referred to as the 'CAA'). In some countries, consumer arbitration is considered either as absolutely unacceptable or a mere redundancy, with a view to strict requirements for validity of an arbitration agreement when judicially reviewing arbitral awards in consumer matters. The consumer is namely often committed to accept the jurisdiction of a court of arbitration in circumstances which are deemed unfair, and the whole process of arbitration often provides no safeguards for the protection of a 'weaker party' - the consumer.

The Slovakian approach to the issue, nevertheless, allows for consumer arbitration but only upon a specific and explicit consumer arbitration contract not only a clause in a contract. This 'must be written, both in content and formally separated from the consumer contract, and shall not include arrangements that are not related to consumer arbitration' (Sec. 3(2) CAA). Under Sec. 3(5) CAA, moreover, 'conclusion of a consumer arbitration contract must not be a condition for the conclusion of a consumer contract.' In addition, contrary to the commercial arbitration, under Sec. 3(6) CAA

consumer arbitration contract does not restrict the consumer's right to turn to a court. The consumer, despite the conclusion of a consumer arbitration contract, may claim their rights by bringing an action before a court and the supplier or their legal successor cannot effectively rely on the lack of jurisdiction of the court under a special regulation, unless the matter has previously been solved in a consumer arbitration.

The foregoing provisions should be of sufficient evidence to the reader that the consumer arbitration in Slovakia is a sui generis proceeding that does not build on the principles of international models for commercial arbitration (the UNCITRAL Model Law). Additionally, various specific requirements are imposed both on the arbitration court (Sec. 10 et seq. CAA) as well as on the arbitrators (Sec. 4 et seq. CAA), who may incur specific disciplinary liability (Sec. 48 et seq. CAA). All this is in order to provide for greater consumer protection within the arbitration under the CAA.

16 This is suggested also by Abdel Wahab (2012) 425. 
Finally, to move towards the examined issue of electronisation of arbitration proceedings, Sec. 3(2) CAA provides that 'the written form of a consumer arbitration contract is maintained even if it was concluded by electronic means enabling the preservation of content and identification of the contracting parties that concluded the consumer arbitration contract.' Furthermore, Sec. 3(3) requires that consumer arbitration contract also contains a 'link to a website of the permanent court of arbitration, where the rules of procedure of the permanent court of arbitration ... are published, as well as updated information according to Sec. 18(3) and the address for electronic communication', which can also be considered a sign of actual electronisation of consumer arbitration.

In this spirit and in accordance with Sec. 12 CAA, 'the founder is obliged to establish, provide for the operation and updating of the website on which there is disclosed information in a clear, easily understandable and user-friendly form on the permanent court of arbitration', to the extent given in the relevant provisions of the CAA.

The provision of Sec. 22 et seq. CAA once more, as in the AA, does not provide expressly for electronic form of filing an action (motion). However, should the Rules of Procedure of the court provide for such an opportunity, this can not be excluded a priori, based on the subsidiary applicability of the general regulation on court proceedings in the Slovak Republic, ${ }^{17}$ as well as with respect to Sec. 11(3) letter c) CAA on the necessity of the arbitral tribunal to prove 'sufficient technical, software and administrative facilities and equipment that allows for the reception of filings' as required under special rules - EU Regulation no. 524/2013 of 21 May 2013 on consumer ODR.

Sec. 31 CAA is somewhat differently from the AA with respect to the venue of the proceedings. It formulates a principle that 'consumer arbitration shall be held at the seat of the permanent court of arbitration,' even though Sec. 31(2) allows for, just like AA, that 'if this does not hinder the right of a party to have access to a court, an arbitration court may carry out various actions in place, which it deems appropriate, particularly for hearing witnesses, experts or parties to the consumer arbitration, examination of goods, property or documents.' In theory, therefore, the use of electronic means of communication and electronic form of proceedings seems acceptable even in the consumer arbitration, especially should the Rules of Procedure introduce a fiction that the proceedings are considered to be held in seat of the court of arbitration even if conducted electronically.

It is important, however, to note that the CAA does not provide for such a freedom in relation to the Rules of Procedure as the AA does in case of commercial arbitration. Sec. 15(2) CAA namely explicitly requires that 'the principles of procedure and proceedings before the permanent court of arbitration contained in the rules of procedure must ensure equality of parties to the consumer arbitration and the right of each party to the consumer arbitration to act before the permanent court of arbitration, as well as the protection of rights and legitimate interests of consumers.' According to Sec 70 CAA, similarly,

consumer arbitration agreement, statutes, rules of procedure or other rules of the permanent court of arbitration may not deviate from this Act to the detriment of the consumer. Invocation of the statutes, the rules of procedure and other rules of the permanent court or arbitration should not lead to disadvantages for the consumer compared to the supplier.

17 Sec. 71(1) CAA: 'If some issues of the proceedings can not be resolved under this Act, general provisions on court proceedings shall apply mutatis mutandis, if the nature of the case allows for this.' The general regulation is the Code of Civil Contentious Litigation (as of 1 July 2016 replacing the previous Code of Civil Procedure) 
Thus, it seems the rules on electronic arbitration with a fiction of proceedings taking place in the seat of the court could be considered in harmony with the principles of the CAA, unless those provisions were to the detriment of the consumer. This also depends on how such provisions of the Rules of Procedure would be evaluated by the Ministry of Justice of the Slovak Republic, with respect to Sec. 11(3) letter 1) CAA, under which the founder of a court must prove to the Ministry that 'the statutes and rules of procedure are consistent with this Act' in order to obtain an authorization for establishment and operation of a court of arbitration under the CAA. Unfortunately, no similar problem has so far been presented to the Ministry.

The more specific issue of electronic service and delivery, according to Sec. 33(3) CAA, the

documents with the exception of the court action and decisions of the permanent court of arbitration may be served by electronic means, if the party to the consumer arbitration notifies the permanent court of arbitration of its address for sending documents by electronic means, and requests the service of documents exclusively by electronic means, or if the parties stated in the arbitration contract an address for sending documents by electronic means and agreed to electronic method of serving documents.

The court documents shall thereby be considered delivered on the fifth day from the dispatch, even if the addressee has not read the message. However, delivery to an e-mail address stated in the consumer arbitration contract is effective only if the party to the consumer arbitration confirms the electronic address in the subsequent electronic communication. Finally, under Sec. 33(5), the consignment is also deemed to be delivered upon meeting the conditions of a special regulation (Act on e-Government) by delivery to the electronic mail box of the party.

Still, under Sec. 33(3) CAA, it is impossible to regulate the serving of the court action (or award) by other electronic means or to another e-mail address than to the electronic mailbox established under the Act on e-Government. There is no possibility for the Rules of Procedure to deviate from these principles as different rules would be in an apparent contradiction with the CAA, which is prohibited in the above cited Sec. 11(3) letter 1) CAA, under which the founder, in order to obtain permission to establish and run a court of arbitration, must demonstrate that 'the statutes and rules of procedure are consistent with this Act.'

Another obstacle is, as in the AA, the restriction with regard to the form of the arbitral award. Sec. 40 CAA namely requires that an arbitral award is always executed in a paper form. Rules of Procedure in contradiction with this provision are again precluded by Sec. 11(3) letter 1) CAA.

Finally, for the sake of completeness, the recognition and enforcement of arbitral awards issued in consumer disputes in the territory of a State other than the Slovak Republic is regulated by the same principles as in case of commercial arbitration, Thus, the commentary on this issue in the previous subchapter is relevant for this situation.

In conclusion, the electronic/online form of consumer arbitration seems admissible in Slovakia to a similar extent as with the commercial arbitration, with the same basic limitation - the impossibility of issuing awards in an electronic form. However, there are also some other restrictions, such as with regard to the place of arbitration and serving of the action (motion) and decisions by the court, where the Rules of Procedure must not be in 
conflict with the CAA, and must not be applied to the detriment of the consumer. The abovementioned limits have not yet been tested in practice, since no court of arbitration has used the options of e-arbitration in consumer disputes so far.

\subsection{Specific alternative dispute resolution in consumer disputes}

Several states have introduced various other forms of alternative dispute resolution for consumer disputes in place of arbitration. ${ }^{18}$ This solution was then taken over by the European Union in a specific secondary EU law in relation to the settlement of cross-border (online) consumer disputes: ${ }^{19}$

a) Directive on consumer ADR, i.e. the European Parliament and Council Directive 2013/11/EU of 21 May 2013 on consumer ADR amending Regulation (EC) no. 2006/2004 and Directive 2009/22/EC, and

b) Regulation on consumer ODR - i.e. the Regulation of the European Parliament and of the Council (EU) no. 524/2013 of 21 May 2013 on consumer ODR amending Regulation (EC) no. 2006/2004 and Directive 2009/22/EC.

As of 9 January 2016, special online platform for settlement of cross-border disputes arising out of electronic commerce (hence not arising otherwise than online) was established, ${ }^{20}$ taking a form of an interactive website for consumers and suppliers who seek to resolve their disputes from online transactions extra-judicially (out-of-court) based of the said rules. The EU Commission is the entity responsible for the development, operation and maintenance of the platform and for ensuring all the technical equipment necessary for its operation.

The platform is providing general information on alternative dispute resolution between suppliers and consumers arising from purchase contracts or contracts for services provided online. It allows consumers and suppliers to submit complaints by filling in an electronic complaint form available in all official EU languages, with the relevant documents attached. Complaints are then forwarded to the national alternative dispute resolution entity competent to resolve the dispute in question (for Slovakia, see infra). The platform also offers a free electronic case management tool, enabling the entities to resolve a dispute through the platform, online. Dispute resolution entities are nevertheless not required to use the electronic case management tool and can hence decide the disputes also offline.

This platform therefore allows for and facilitates cross-border communication for consumers, suppliers and entities of alternative consumer dispute resolution. While in Slovakia, originally, the courts of arbitration under the CAA in Slovakia were entrusted this task, the new EU rules caused that recently a new Act was enacted and became effective in the Slovak Republic, introducing new entities and ways of resolving consumer disputes outside the CAA framework, along the lines of the Directive 2013/11/EU. ${ }^{21}$

18 Fogh Knudsen and Balina (2014) 944-48.

19 Cf. Cortés (2011).

20 See the online platform of the Online Dispute Resolution (2017) link 7.

${ }^{21}$ Efforts to introduce other ways of consumer dispute resolution than arbitration have been around for a longer period and rely in particular on the economic unsustainability of arbitration, with the high costs of decision-making in small consumer disputes. See Alternative Dispute Resolution Guidelines: Agreement between Consumers International and the Global Business Dialogue on Electronic Commerce (2003) link 8. 
According to the Explanatory Memorandum to the new Slovak legislation (Act. no. 391/2015 Z.z.), ${ }^{22}$

the aim of the new institute of alternative dispute resolution is to create new opportunities for consumers to resolve their disputes with the supplier quickly, efficiently, less formally and mostly free or with minimal costs compared to currently existing forms of dispute resolution, e.g., mediation, arbitration or judicial proceedings. The aim of the entire dispute resolution procedure before an entity is to reach an amicable solution, respectively an agreement between the consumer and the supplier on the settlement, which becomes legally binding upon the agreement by both parties on the wording of the settlement.

In essence, the procedure is consumer mediation in nature. More specifically, the outcome should take the form of a dispute settlement under Sec. 16(1) letter a) the relevant Act. The Act also specifically emphasizes that the only party entitled to submit a proposal to resolve the dispute through the procedure stipulated by this Act is a consumer, and the process thus cannot be launched by the supplier.

The Act divides the alternative dispute settlement entities into 'ADR bodies' and 'competent authorities'. The ADR bodies are under Sec. 3(2) of the Act those public authorities, which have the obligation entrusted by law to settle disputes falling within their substantive scope of competence. The ADR bodies became the alternative dispute resolution entities ex lege and are included in the list of entities maintained by the Ministry of Economy. These are the ADR body for the settlement of disputes in regulated industries (Regulatory Office for Network Industries), for electronic communications and postal services (Regulatory Authority for electronic communications and postal services) and the Act additionally provides also for a residual ADR body which is the Slovak Trade Inspection (hereinafter referred to as 'STI'). The exception to the competence of the STI are disputes arising from the provision of financial services, which are excluded from the competence of ADR bodies under this Act. The reason is that the regulation of financial services alternative dispute resolution falls under the competence of the Ministry of Finance, which is to prepare a separate law that will create a specific ADR entity for consumer disputes with financial services providers.

In addition to the ADR bodies designated by the Act itself, other entities can also become alternative dispute resolution entities notified to the European Commission, provided these will be authorized by the Ministry of Economy of the Slovak Republic as 'competent authorities'. A legal person shall be entitled to provide alternative dispute resolution in consumer disputes as a 'competent authority' under this Act immediately upon its entry in the list of alternative dispute resolution entities maintained by the Ministry. A condition for such a registration is the submission of an application and fulfilment of the conditions stipulated by the Act. Under Sec. 4 of the Act, a request for inclusion in the list may be submitted to the Ministry by any legal entity created or established for purposes of consumer protection, a professional chamber established by law, or an interest group consisting of at least ten legal entities. Upon the registration, legal entity is authorized to provide the alternative dispute resolution services in the area as entered in the list.

22 Explanatory Memorandum to Act. no. 391/2015 Z.z. (2015) link 9. 
The actual dispute resolution is thereby not characterized in the Slovakian Act as a specific online dispute resolution, unlike it is the case in the Regulation (EU) no. 524/2013 of 21 May 2013 on consumer ODR. Only in Sec. 10(5) of the Act it is stated that the ADR entity which is competent to resolve disputes arising from contracts concluded under a special regulation (Act no. 22/2004 Z.z. on electronic commerce) is obliged to publish on its website a link to the platform for online alternative dispute resolution under a special regulation (Art. 5 of European Parliament and Council Regulation (EU) no. 524/2013 of 21 May 2013 on consumer ODR). The Slovakian Act thus only refers to the possibility of online cross-border consumer dispute resolution (in case of disputes arising from e-commerce) through the abovementioned EU platform, and at the national level leaves the option open for the national consumer dispute resolution entities to decide both online and offline disputes. Unfortunately, no details on electronisation of such procedures are included in the Act which may be the reason for current underdevelopment and lack of use of these possibilities in Slovakia. Electronisation of the proceedings before an alternative dispute resolution entity for consumer disputes is partly mentioned in Sec. 21 of the Act only. Under this section, documents are to be served either by electronic means or by regular mail, while the electronic delivery requires neither an advanced electronic signature nor delivery to an electronic mailbox under the Act on e-Government -

documents are delivered by electronic means, should the motion for ADR proceeding contain an email address where to send documents electronically, or should the address be publicly available... Documents served by electronic means shall be deemed delivered on the third day from their dispatch, even if the addressee has not read these.

\section{ELECTRONISATION OF JUDICIAL PROCEEDINGS IN SLOVAKIA}

Electronisation and modernization in relation to dispute resolution takes place not only within arbitration or other forms of alternative dispute resolution. Court trials are namely also facing various forms of electronisation e.g., electronic submissions, delivery, notification (especially in non-contentious litigations electronisation serves the specific purpose of publicity), or the use of means of electronic communication for hearing witnesses. This section introduces the routes of electronisation acknowledged by the Slovakian legislator in the recent recast of the civil procedural law in Slovakia. This is not a complex regulation and many important regulations are still desired but the problems tackled by the legislator in Slovakia can at least serve as a guide for any possible legislator embarking on a similar road of modernization of court procedure.

Still, it is important to note before exploring the Slovak example, that court trials face electronisation not only within the actual course of the proceedings but also in relation to the fundamental issues of determining jurisdiction of the court, e.g. if the incident occurred in the virtual (cyber)space, particularly with some cross-border elements. This issue is, however, not addressed in the codes of civil litigation in Slovakia, but rather is regulated under the Brussels regime in situations with an EU dimension, or under the Slovakian Act on Private International Law and Procedure no. 97/1963 Zb. for situations outside the Brussels regime. The basis of the Brussels regime is at present the revised Brussels I 
Regulation, Regulation no. 1215/2012. ${ }^{23}$ The revised Regulation has not brought major changes in relation to cyberspace and jurisdiction, and at this point, the conclusions of the recent literature ${ }^{24}$ and to the case law of the Court of Justice of the European Union (CJEU) should be used for further reference. ${ }^{25}$

\subsection{Code of Civil Contentious Litigation}

The new Slovakian Code of Civil Contentious Litigation no. 160/2015 Z.z. (hereinafter referred to as the 'CCL'), effective as of 1 July 2016, addresses several aspects of electronisation of court proceedings. First and foremost, electronic form of submission is recognized (in Sec. 125(2) CCL) just like the previous Code of Civil Procedure (from 1963, with numerous amendments) but with the difference that the qualified electronic signature is required only if the submission concerns the merits of the case. The substantive deadline for completion of the submission in case of missing electronic signature is fixed at 10 days. Sec. 121(5) CCL additionally states, regarding time-limits, that 'the time-limit is met should the act be performed in court at the final day or should the motion be handed over to a body which has the duty to deliver the motion; the same applies should the motion submitted by electronic means be received by the court after its office hours.'

In addition, a number of procedural acts of the parties and of the court are allowed to take an electronic form under the new CCL. For example, according to the Explanatory Memorandum to Sec. $100 \mathrm{CCL}$, concerning the summons, 'equivalent forms of writing are both the paper form as well as electronic form ... In cases where the principle of procedural economy makes it possible, paper summons may be replaced by more efficient means of communication.' To this end, the provision of Sec. $136 \mathrm{CCL}$ also recommends to include the e-mail addresses of the parties as a part of filing the court action. Similarly, pursuant to Sec. 183(4) CCL, the party proposing adjournment of a hearing is required to provide its telephone number or electronic address through which it can be notified of the court decision on the proposal for adjournment.

Furthermore, the CCL brings about major changes especially with respect to service and delivery. According to the Explanatory Memorandum to Sec. 105 CCL,

the proposed concept of serving has the potential to significantly streamline and accelerate proceedings by introducing new elements of modern electronic communication with the parties ... The documents which are not to be delivered into own hands are preferentially served by electronic means, including electronic mailbox under the Act no. 305/2013 Z.z. on electronic exercise of competences of the public authorities ... (the Act on e-Government)...

${ }^{23}$ Its predecessor was the Brussels I Regulation, Council Regulation (EC) No. 44/2001 of 22 December 2000 on jurisdiction and the recognition and enforcement of judgments in civil and commercial matters, preceded by the so-called Brussels Convention of 1968 concluded between the States of the European Community, and the Lugano Convention of 1988 relating to the EFTA countries and other countries outside the EU.

${ }^{24}$ E.g. Savin (2011) 21 link 10. See also Svantesson (2012) 256.

25 From among the decisions of the CJ EU it is notably the case of e-Date and Olivier Martinez, and further the cases: Wintersteiger, Pammer v Reederei Karl Schlüter GmbH \& KG, or Alpenhof GesmbH v Oliver Heller. 
The provisions of Sec. 105(2) CCL allow the party to choose another electronic address for delivery service as well. Where a party requests delivery to a different e-mail address, the court does not further investigate whether the party become familiar with the document and considers it to be delivered within three days after it was dispatched.

In addition, Sec. 106 and Sec. 115-116 CCL foresee service by notification, respectively via a public notice on the notice board of the court, and (in case of a public notice 'or') on the website of the court. Similarly, under Sec. 219(3) CCL, in cases in which the court decides by judgment without a hearing, the venue and the time of public announcement of the judgment are to be published on the notice board of the court and on the website of the relevant court at least five days prior to its announcement. If requested by the parties, the court shall notify them of the place and time of public announcement of judgment through electronic means.

The provision of Sec. 98 CCL deals with the recording of hearing where, in the spirit of recent practice in Slovakia it is assumed that the hearing be recorded with the use of a technical device capable of recording sound. Thus drawn record is to be stored on a data carrier and after the hearing is to be attached to the case file, or a note is to be made into the court file on where the record is stored. The records are supposed to form a part of the socalled electronic court case file, where the litigants, respectively their legal representatives should be allowed access to the files online. The first experiences with this option at the level of district courts are already at hand - so far not indicating any major problems.

Under Sec. 175(2) CCL there is also an option that the court may, with the consent of the parties hold a hearing through a videoconference or other communication technology means. ${ }^{26}$

In relation to taking evidence, respectively the use of electronic evidence and the legality and admissibility of such evidence, the Explanatory Memorandum to Art. 16 of the basic principles of the CCL even provides that

the court may accept evidence obtained in violation of the law if the counterparty's right is considered under the rules of constitutional law as stronger in that particular case than the violated right of the person at whose expense the evidence is accepted. Thus if, for example, the court takes into account an electronic communication or video and audio recording made by electronic means, which had been obtained without the consent of the person whose personality features and expressions were recorded, this must be justified by the fact that the personality rights of the person in this particular case are proportionally weaker than the right of the counterparty, the violation of which is to be demonstrated through the use of thus obtained evidence (as stated by the previous case law, this may be e.g. the proportionally stronger interest in protection of the racial, gender, or other equality).

Electronic communication is also regulated within the CCL provisions on urgent measures, where Sec. 325(2) letter g) CCL allows for imposition of urgent measures consisting in prohibition to contact in writing, by telephone, electronic communication or through other means, in whole or in part, a person whose bodily integrity or mental integrity can be compromised by such contact.

${ }^{26}$ Under Sec. 175(3) CCL the following applies in addition: 'The course of the hearing can be recorded by a party or its representative via technical devices intended for recording sound; the court is to be notified of this in advance.' 
Finally, the CCL also envisages the use of electronic monitoring means ${ }^{27}$ in civil matters. Under Sec. 325(3) CCL, upon meeting conditions stipulated by a special regulation, the court may order to monitor compliance with urgent measures with the use of technical means. Unfortunately, this option, introduced similarly also in the criminal proceedings, has not, so far, been used in Slovakia at all.

The above enumeration clearly shows that the electronisation of court procedure is only partially included in the new Code. Nevertheless, the cautious approach is to be explained also by the possible risks and dangers connected to the electronisation and onlineadministration of justice.

\subsection{Code of Civil Non-Contentious Litigation}

Non-contentious civil litigation is regulated as of 1 July 2016 in the Code of Civil NonContentious Litigation, Act no. 161/2015 Z.z. (hereinafter referred to as 'CNL'). It contains a number of specificities in comparison with the civil contentious litigation. These are also manifested in some aspects of electronisation of the court procedure. For example, Sec. 34 CNL states that 'provisions of the Code of Civil Contentious Litigation on recording of procedural act by technical devices capable of recording sound shall not apply in proceedings conducted by the notary public, acting as a court commissioner.'

Otherwise, in general, electronisation is used in the CNL to ensure the publicity of some procedural acts. For example, closely linked to the aforementioned activities of public notaries in respect of inheritance proceedings, in Sec. 190(2) CNL, notification via public notice is regulated and published 'on the notice board of the court, the website of the relevant court and on the web site of the Chamber of Notaries of the Slovak Republic. The public notice can also be published through the mass media.'

Similarly, under Sec. 199 CNL, the court shall issue a resolution calling on creditors to notify their claims against the inheritance within a period specified in the resolution, which shall not be less than one month, upon a proposal by the heirs. The court resolution is to be published on the official notice board of the court, on the website of the relevant court and on the website of the Chamber of Notaries of the Slovak Republic. The court proceeds similarly in case of a resolution ordering the liquidation of inheritance under Sec. $205 \mathrm{CNL}$ and in case of publication of a notice, in which the court informs domestic heirs and creditors that the property shall be transferred to a foreign country (Sec. $213 \mathrm{CNL}$ ).

The use of electronic communication, especially to guarantee publicity, is a common feature in many specific non-contentious proceedings regulated in the CNL. Thus, under Sec. $226 \mathrm{CNL}$, proclamation of death is to be published by a public notice on the official notice board of the court and on the website of the relevant court.

Under Sec. $326 \mathrm{CNL}$, in case of proceedings on annulment of lost documents, notification on initiation of the proceedings is to be published on the official notice board of a public notary who issued the notification, and on the website of the Chamber of Notaries of the Slovak Republic. The notification is also to be published on the official notice board of the relevant court and on the website of the court.

In case of deposit proceedings, under Sec. 354(1) CNL, the court shall issue a resolution on the initiation of deposit proceedings whereby those who have the right to the deposit are to be invited to make a request to surrender the deposit, addressed to the notary public, with advice that if nobody makes the request within three years from the date

27 See Electronic monitoring services (2017) link 11. 
of issuing of the resolution, the object of deposit will be forfeited as a property of the State. The resolution is to be served on the parties and published on the official notice board of the court and on the website of the court.

Finally, in relation to enforcement of decisions regarding minors, pursuant to Sec. 385(1) CNL, the court shall notify the authorized person of the place and time of the execution in writing, via electronic means or via telephone.

Just like in the previous Code of Civil Procedure, specific regulation was maintained with respect to objections against the refusal of registration by the Commercial Registry. According to Sec. 288 CNL, objections can be filed electronically. Objections must be submitted through an electronic form published on the central portal of public administration and must be authorized by the claimant; otherwise the Commercial Court shall not take the objections into consideration.

It can be clearly seen that the use of electronisation within the non-contentious litigation is even more restricted than within the contentious litigation.

\subsection{The Code of Administrative Judicial Proceedings}

Administrative Justice (regulated in Slovakia since 1 July 2016 by the Act no. 162/2015 Z.z., the Code of Administrative Judicial Procedure, hereinafter referred to as 'AJP') shows again a few deviations with respect to electronisation in comparison with the civil contentious and civil non-contentious litigation.

According to Sec. 32(4) AJP a waiver of participation in proceedings before the Administrative Court can be done either orally on record during the hearing, or in a paper form with a signature certified by public notary, or finally electronically, with the use of advanced electronic signature.

The common element with the CCL is the provision of Sec. 56 AJP stating that a motion can be done in writing, meaning either in paper form or electronically. Motions, made electronically without authorization, must additionally be delivered in paper form or authorized electronically under a specific Act; if not amended within ten days, the motion shall be disregarded. The court does not invite the parties to amend the submitted motion.

Similarly, the provision of Sec. 69 AJP copies the rule laid down in the CCL on the issue of compliance with the deadline in case of filing a submission by electronic means outside the office hours of the court.

Conceptually identical with the CCL is also the provision in Sec. 72 AJP on the electronic serving of judicial documents - either into the electronic mailbox under a special regulation, or upon request of a party to an email address designated by the party. Administrative Court documents are then to be considered delivered on the third day from the dispatch, even if the addressee has not read these.

As in the CCL, the AJP in its Sec. 75 regulates the public notice being published on the official notice board of the Administrative Court or on the website of the relevant Administrative Court.

Also, as in the CCL, the provision of Sec. 76 AJP governs summons, whereby again, under the Explanatory Memorandum, written form means equally paper form and electronic form.

Recording of the hearing by technical equipment, regulated in Sec. 117 AJP, basically copies the rules laid down in the CCL - the court has the duty to record the hearing, and with the consent of the parties it may hold a hearing through video conference or through other communication technology tools. 
According to Sec. 108(3) AJP, a notice of hearing is to be published by the Administrative Court also on the website of the Court. Similarly, pursuant to Sec. 116 AJP, in the case where it is not possible to pronounce the judgment immediately after the hearing, the presiding judge shall notify the absent parties of the date of delivery of the judgment through the website of the Court. Similarly, pursuant to Sec. 137 AJP, in cases in which the Administrative Court decides without an oral hearing, the venue and the time of public announcement of judgment is to be published on the notice board of the Court and on the website of the relevant Administrative Court at least five days prior to the announcement of the judgment.

\subsection{Serving the documents under the Act on e-Government}

The electronisation and modernisation of judicial proceedings in Slovakia is closely linked to the Act on electronic exercise of competences of the public authorities no. 305/2013 Z.z. (Act on e-Government). This is mainly due to the rules on serving into electronic mailboxes, which are referred to in the new procedural codes. This issue requires some attention. Based on the Act on e-Government, at the turn of 2013 and 2014, all public authorities, legal entities, natural persons and natural persons-entrepreneurs in the Slovak Republic were attributed an electronic mailbox. Upon activation of these mailboxes, which takes place automatically in case of public bodies or upon request in case of other entities, electronic documents will be delivered into these mailboxes, including those designed into own hands, hence also including the judgments in electronic form. Electronic mailboxes became mandatory for all legal persons as of 1 July 2017.

Under Sec. 32 of the Act on e-Government, electronic documents shall be deemed delivered if

a) the addressee is a public authority, upon storage of the electronic message in the mailbox,

b) the addressee is not a public authority and the document is to be delivered into own hands, ${ }^{28}$ as of the day, hour, minute and second stated on the automated electronic deposit confirmation, ${ }^{29}$ or upon expiry of the storage period, ${ }^{30}$ whichever comes earlier, even should the addressee not gain knowledge of the delivery,

${ }^{28}$ Under Sec. 29(3), delivery into own hands for the purposes of electronic delivery means delivery that requires confirmation of receipt in a form of delivery confirmation by the addressee or any person entitled under special regulations to accept deliveries instead of the addressee.

29 Under Sec. 30, delivery confirmation is an electronic document indicating the date, hour, minute and second of the electronic delivery, the person of the recipient, the sender, and identification of the electronic message and of electronic documents delivered electronically. If the addressee is a public authority the delivery confirmation is made by the electronic registry of that authority. If the addressee is not a public authority, a delivery confirmation is issued automatically by the electronic delivery module, and the governmental office through the module of electronic mailboxes ensures that in accepting delivery of any document the recipient always has to confirm the delivery prior to being able to access the documents. Delivery confirmation is electronically delivered to the mailbox of the sender of the electronic message, acknowledging the receipt of the delivered communication.

30 The storage period for the purposes of this Act is the period during which the stored electronic message is considered as undelivered. The storage period is 15 days from the day following the date of deposit of electronic message in the mailbox, unless special legislation provides otherwise. 
c) the addressee is not a public authority and the document is not to be delivered into own hands, as of the day immediately following the delivery of the electronic message into the mailbox.

The recipient is obliged to confirm receipt via a delivery confirmation if delivered electronically into their own hands. Confirmation of delivery is a precondition for making the message accessible to the recipient in their electronic mailbox.

If the electronic delivery occurs on a day of public holiday or on any non-working day, where the beginning of a time limit for action or for performing an act is linked to the moment of electronic delivery, such time limit shall commence as of the following business day. This however, does not apply, should special legislation provide otherwise, or should the nature of the act or transaction require that a public authority or other person act even on a day which is a day of public holiday or a non-working day.

As a matter of exception, should the legal effect of delivery be too harsh, according to Sec. 33 of the Act on e-Government, a public authority acting in a matter where the electronic delivery is concerned, may, on a proposal from the recipient which is not a public authority, rule that the electronic delivery is ineffective, should the recipient prove that:

a) the recipient objectively could not access the electronic message for a reason that did not arise on the side of recipient or within recipient's scope

or

b) on the side of the recipient reasons occurred which objectively did not prevent the recipient from accessing the electronic message, but accessing the message would have entailed such disproportionate difficulties that it would not be fair to demand the recipient to overcome these.

Such a proposal must be made within 15 days from the date on which the addressee became familiar or could become familiar with the electronic message. The proposal must, in addition to general requirements of any proposal under rules concerning that proceeding in which the message was delivered, also contain the date on which the addressee became or could have become familiar with the electronic message, and the evidence relied upon. However, the motion cannot be made after the entry into force of a judgment on divorce, or a judgment which held that a marriage is invalid or that there is no marriage at all.

A public authority may decide on ineffectiveness of electronic delivery on its own motion if it is clear from the files that the addressee could not have got acquainted with the electronic message within the storage period.

A public authority that decides on ineffectiveness of electronic delivery may also decide to delay the effects of electronic delivery up until the decision on the merits of the case is reached, should the addressee face serious damage and the postponement would not cause any damage to the rights of third parties acquired in good faith, nor harm the public interest in excess of the damage imminently faced by the addressee.

If a public authority decided that electronic delivery was ineffective, electronic message including any electronic documents shall be considered delivered as of the date when the decision on the ineffectiveness of electronic delivery came into effect. The decision on the ineffectiveness of electronic delivery is subject to appeal or other measures pursuant to special legislation regulating the proceedings in which the delivery was made. Should the ineffectiveness of electronic delivery be determined by an authority other than a court, the decision on the ineffectiveness of electronic delivery is subject to judicial review. 


\section{CONCLUSIONS}

This article has demonstrated the wide range of electronisation of the judicial proceedings as well as alternative dispute resolution proceedings in the Slovak Republic. Having chosen Slovakia as an example here, only some of the possible routes of electronisation of procedural law were introduced. However, even in such a way possible deficiencies and omissions can be pointed out for the needs of other (foreign) legislators and legislation drafters - specifically for the countries of Central and Eastern Europe, where numerous recasting efforts are present in various branches of law, including the procedural law. This article thus serves as a call for careful pondering upon the benefits but also risks and dangers of electronisation of law, and of the procedural law in particular.

In this respect, it is concluded that arbitration as a sort of dispute resolution may also take a mostly electronic (online) form in Slovakia, with the exception of issuing arbitration decisions which must both under the Arbitration Act and the Consumer Arbitration Act be issued in a paper form for the sake of legal certainty. Making the last move towards a fully electronic (online) dispute resolution could thereby not be a major problem, making thus the country and its legal system an interesting key player in international arbitral dispute resolution.

Alternative dispute resolution in consumer disputes, taking a form of a mediation settlement, is a novelty introduced in Slovakia (and other countries) only under the influence of specific EU Regulation and Directive which also established an electronic platform to facilitate cross-border communication in resolving consumer disputes. At the national level, however, electronic course of action in these matters is not provided for explicitly in the relevant Act of the Parliament. Nevertheless, it is also not prohibited nor excluded.

At the level of court proceedings, electronisation has not reached a stage yet where the decision would be fully entrusted to a machine, as it was expected by Czechoslovak legal theoreticians in the 1960s. ${ }^{31}$ Still, in civil proceedings, various procedural enhancements connected to the electronisation have taken place in Slovakia recently - in addition to the possibilities of electronic submissions, hearings can also take place with the use of electronic means, public notices are published on the websites of the courts and relevant authorities, and service of documents was also widely electronised, mostly being based on a special Act on e-Government. Still, the changes introduced, albeit a form of modernisation, are still very cautious, taking into account possible risks and dangers, as well as the existence of a large number of population which might have been placed at disadvantage by the electronisation, due to their inability to use the modern technology.

Finally, it should also be noted that the electronisation of procedural law is also closely related to electronisation of the legal professions - especially with the use of electronic mailboxes under the Act on e-Government but also when using electronic signatures, laptops and smartphones while working outside the office, or when saving the data and information in the cloud or on foreign servers, where the professionals have their mailboxes and websites hosted. ${ }^{32}$ The electronisation of dispute resolution thus takes various forms in which it is manifestly present worldwide and this trend is undoubtedly yet to rise in the future.

${ }^{31}$ Knapp (1963). See more in Polčák (2012) 46 et seq.

32 Cf. ABA Client Confidentiality and Lawyers use of technology: Issues Paper Concerning Client Confidentiality and Lawyers' Use of Technology (2010). Cf. also: Hill (2010). 


\section{LITERATURE}

Abdel Wahab, Mohamed S., 'ODR and e-Arbitration Trends \& Challenges' in Abdel Wahab, Mohamed S., Katsh, Ethan and Rainey, Daniel (eds), Online Dispute Resolution: Theory and Practice: A Treatise on Technology and Dispute Resolution (Eleven 2012).

Abdel Wahab, Mohamed S., Katsh, Ethan and Rainey, Daniel (eds), Online Dispute Resolution: Theory and Practice: A Treatise on Technology and Dispute Resolution (Eleven 2012).

Albornoz, Maria M. and González Martín, Nuria, 'Feasibility Analysis of Online Dispute Resolution in Developing Countries' (2012) 1 The University of Miami Inter-American Law Review 39-61.

Brand, Ronald A., 'Party Autonomy and Access to Justice in the UNCITRAL Online Dispute Resolution Project' (2012-2013) 10 Loy. U. Chi. Int'l L. Rev. 11-36.

Breaux, Paul W., 'Online Dispute Resolution: A Modern ADR Approach' (2015) 5 The Computer \& Internet Lawyer 178-81.

Cortés, Pablo, 'Developing Online Dispute Resolution for Consumers in the EU: A Proposal for the Regulation of Accredited Providers' (2010) 1 International Journal of Law and Information Technology 1-28.

Cortés, Pablo, Online Dispute Resolution for Consumers in the European Union (Routledge 2011).

Fogh Knudsen, Laine and Balina, Signe, 'Alternative Dispute Resolution Systems Across the European Union, Iceland and Norway’ (2014) 109 Procedia - Social and Behavioral Sciences 944-48.

Hill, Louise L., 'Emerging Technology and Client Confidentiality: How Changing Technology Brings Ethical Dilemmas' (2010) 16 BUJ Sci. \& Tech. L 1-57.

Hörnle, Julia, Cross-Border Internet Dispute Resolution (CUP 2009).

Katsh, Ethan and Rifkin, Janet, Online Dispute Resolution: Resolving Conflicts in Cyberspace (Jossey-Bass 2001).

Knapp, Viktor, O možnosti použití kybernetických metod v právu (On the possibilities of using cybernetic methods in law) (Vydavatelství Československé akademie věd 1963).

Lodder, Arno R. and Zeleznikow, John, Enhanced Dispute Resolution Through the Use of Information Technology (CUP 2010).

Poblet, Marta, Mobile Technologies for Conflict Management: Online Dispute Resolution, Governance, Participation (Springer 2011).

Polčák, Radim, Internet a promény práva (Internet and changes in law ) (Auditorium 2012).

Svantesson, Dan Jerker B., Private International Law and the Internet (Wolters Kluwer 2012).

\section{LINKS}

1. Hörnle, Julia, Encouraging Online Dispute Resolution in the EU and Beyond - Keeping Costs Low or Standards High? (2012) <http://www.e-lawyerassistance.com/ArticlesPDF/Encouraging OnlineDisputeResolutionintheEUen.pdf $>$ accessed 17 July 2017.

2. Online Dispute Resolution (2017) <http://odr.info > accessed 17 July 2017.

3. Chinese Chamber of Commerce (2017) $<$ http://www.cietac.org/index/rules.cms $>$ accessed 17 July 2017.

4. e-Court (2017) <http://www.e-court.nl/> accessed 17 July 2017.

5. Schiavetta, Susan, 'The Relationship Between e-ADR and Article 6 of the European Convention of Human Rights Pursuant to the Case Law of the European Court of Human Rights' (2004) 1 The Journal of Information, Law and Technology (jilt) <http://www2.warwick.ac.uk/fac/soc/law/elj/ jilt/2004_1/schiavetta/> accessed 17 July 2017.

6. Explanatory Memorandum to the Arbitration Act no. 244/2002 Z.z. (print no. 1126) (2002) $<$ https://www.nrsr.sk/web/Dynamic/Download.aspx ? docid = 403099> accessed 17 July 2017.

7. Online dispute resolution $(2017)<\mathrm{https} / / /$ webgate.ec.europa.eu/odr/main/index.cfm?event=main. home.show\&lng=EN $>$ accessed 17 July 2017.

8. Alternative Dispute Resolution Guidelines: Agreement between Consumers International and the Global Business Dialogue on Electronic Commerce (2003) <http://www.gbd-e.org/ig/cc/ Alternative_Dispute_Resolution_Nov03.pdf $>$ accessed 17 July 2017. 
9. Explanatory Memorandum to Act. no. $391 / 2015$ Z.z. <http://www.rokovania.sk/File.aspx/ ViewDocumentHtml/Mater-Dokum-186175?prefixFile=m_> accessed 17 July 2017.

10. Savin, Andrej, Jurisdiction in Electronic Contracts and Torts - The Development of the European Court's Case Law (2011) <http://papers.ssrn.com/sol3/papers.cfm?abstract_id=1919651> accessed 17 July 2017.

11. Electronic monitoring services (2017) < https://www.justice.gov.sk/Stranky/Nase-sluzby/Naseprojekty/Elektronicke\%20sluzby\%20monitoringu/Uvod.aspx > accessed 17 July 2017.

12. ABA Client Confidentiality and Lawyers use of technology: Issues Paper Concerning Client Confidentiality and Lawyers' Use of Technology (2010) <http://www.americanbar.org/groups/ departments_offices/legal_technology_resources/resources/charts_fyis/cloud-ethics-chart.html > accessed 17 July 2017. 